\title{
Tactics of the Governed: Figures of Abandonment in Andean Peru
}

\author{
MATTIAS BORG RASMUSSEN*
}

Abstract. Abandonment has become a performative idiom in Andean Peru, where it retains its purchase despite the investments of the state. Local development is tied to the desire to be governed. In spite of prolonged state presence, the villages' relationship to authorities is continuously and persistently figured as one of abandonment: villages are abandoned because someone is deliberately holding them in such unfortunate conditions. To figure abandonment in village politics is to draw on this idiom as an effective means of both communicating the historical experience of governance and putting forward morally grounded claims to local authorities. The idiom of abandonment is therefore both effective and affective as a critique of governance and a claim to citizenship.

Keywords: Andes, Peru, politics, citizenship, rural development

\section{Introduction}

'They have abandoned us here', Pompeyo noted dryly as we looked at the collapsed slope. ${ }^{\mathrm{I}}$ We were assessing the consequences of a minor landslide, a buaico, that had disconnected the water reservoirs from the tubes leading potable water to the village of Huancapampa in Peru's Cordillera Blanca while also severely damaging the road leading uphill to Ocopampa. The local water committee that Pompeyo presides over had fixed the water provision, but the villagers did not possess the heavy machinery required for the

Mattias Borg Rasmussen is an assistant professor at the Department of Food and Resource Economics, University of Copenhagen. Email: mbr@ifro.ku.dk.

* The author wishes to thank Dan Hirslund, Ben Orlove, Karine Gagné, Karsten Pærregaard, Rudi Colloredo-Mansfeld, Fiona Wilson, Eric Hahonou and Christian Lund for valuable comments to this piece in its earlier versions. I also appreciate the careful attention given to this piece by the $J L A S$ reviewers and editors. All errors are mine. Fieldwork was carried out between 2010-I I thanks to a generous grant from the European Research Council (ERC Grant 229459). Additional fieldwork in 2013 and 2014 was sponsored by the Danish Council for Independent Research (0602-02589B FSE). During fieldwork I was affiliated to the Pontificia Universidad Católica del Perú in Lima.

${ }^{\mathrm{I}}$ Fieldnotes, 24 June 2010. 


\section{Mattias Borg Rasmussen}

reconstruction of the road that many villagers use to drive their herds to the field and carry home the fruits of the harvest on horseback. For this, the villagers relied on the local government in Recuay. Pompeyo was not optimistic about the prospects.

In this article I explore the dynamics of local politics and citizenship in Andean Peru. I focus in particular on a central idiom in local political discourse, 'abandonment'. I analyse how this idiom is used to strategically position local actors and bargain with the state, and thus how villages seek to gain attention and resources from authorities. Against the recent theoretical deconstruction of the state, I am particularly interested in the ways in which the recurrence of terms such as abandonment is used not as an exact representation of state presence, but rather as an effective means of positioning oneself in relation to political allies and opponents. ${ }^{2}$ Highlighting vernaculars of citizenship, the analysis of the desire to be governed shows how local politics is deeply connected to wider processes, historical experiences and ideas about the state. Here, both state and village are mutually constituted and coproduced. In short, I argue that figurations of abandonment in local politics serve as a critique of governance and an exercise of citizenship.

Abandono frequently recurs in local descriptions of the situation in Huancapampa, a rural village near the provincial capital of Recuay in the region of Ancash in northern Peru. When Pompeyo lamented the abandonment of the deteriorated road, he activated a trope that would be readily understood by his peers. The neglect of the road was indicative of a profoundly disrupted relationship between state and citizen, albeit a problem that could be solved by re-establishing the connection. As a vernacular of citizenship, abandonment serves as a leitmotif, conveying the distance from power, cities, comfort, security, dignity, and general support. In virtually all political meetings I attended where matters of local infrastructure were discussed, whether the topic was the lack of state-sponsored 'improved kitchens' (concrete stoves with a small chimney releasing the smoke outside the kitchen), the unfinished electrical grid, or the eroded roads, the term abandonment was used over and again to describe the relationship between villagers and some kind of state benefactor, be it local, regional or national government. The apparent contradictions of the frequent use of the term became evident three months later when I accompanied Don Seferino from Ocopampa to the municipality in order to negotiate the reconstruction of the road directly with the mayor. Now, conveniently close to regional elections, the mayor had offered to

2 See, for example, Begoña Aretxaga, 'Maddening States', Annual Review of Anthropology, 32 (2003), pp. 393-410; Thomas Blom Hansen and Finn Stepputat, 'Introduction: States of Imagination', in Thomas Blom Hansen and Finn Stepputat (eds.), States of Imagination: Ethnographic Explorations of the Postcolonial State (Durham, NC: Duke University Press, $200 \mathrm{I})$, pp. I -38 . 
pay the S/. 900 that a Huancapampa land-owner demanded as recompensation for the land being expropriated by the new road. ${ }^{3}$ An inherent intimacy is closely linked to abandonment. Abandonment is not merely a material condition, but an effect of governance. ${ }^{4}$ Here I discuss the ways in which the villagers of Huancapampa and its adjacent villages figure abandonment in local politics.

Abandonment is therefore also a leitmotif in my analysis. I treat the idiom of abandonment as a central site of meaning for Andean villagers, one through which they understand their historical experiences of being governed, and with which they comment on and connect to local politics of influence. I suggest that the presence of states in local affairs is due not only to the power of state institutions but also to the co-production of statehood and personhood in a variety of settings. In Huancapampa, the state can be both only partially present and palpably absent. The state may appear as bureaucrats, mayors, peasant patrols, engineers, law enforcement, documents, legislation, and so on, what Gupta calls a 'disaggregated state'. 5 I seek to understand how people living on the margins of Peruvian society perceive and position themselves in relation to an erratic and seemingly disinterested state apparatus, and how they try to gain influence over decisions made in their vicinity that will affect them, directly or indirectly.

As in the scholarly literature, Peruvians themselves often characterise small villages in Andean Peru as being in competition for resources. ${ }^{6}$ One of the key resources for which villages compete is the ability to connect productively with authorities. This article traces the attempts of the inhabitants of Huancapampa to transform their administrative definition from that of 'village' (and therefore 'rural') to that of 'minor populated settlement' (centro poblado menor), therefore 'urban' and thus eligible for a variety of structural and economic benefits

${ }^{3}$ Fieldnotes, I 4 September 2010.

${ }^{4}$ See also João Biehl, 'Technologies of Invisibility', in Jonathan Xavier Inda (ed.), Anthropologies of Modernity: Foucault, Governmentality, and Life Politics (Oxford: Blackwell, 2005), pp. 248-7I; Bridget Love, 'Treasure Hunts in Rural Japan: Place Making at the Limits of Sustainability', American Anthropologist, i I 5: I (2013), pp. I I $2-$ 24; Elizabeth A. Povinelli, Economies of Abandonment: Social Belonging and Endurance in Late Liberalism (Durham, NC: Duke University Press, 201 I).

5 Akhil Gupta, Red Tape: Bureaucracy, Structural Violence, and Poverty in India (Durham, NC: Duke University Press, 2012), p. 41. See also Rudi Colloredo-Mansfeld, Fighting like a Community: Andean Civil Society in an Era of Indian Uprisings (Chicago, IL: University of Chicago Press, 2009), p. I9.

${ }^{6}$ Romeo Grompome and Rodrigo Barrenechea Carpio, 'Consejos municipales en ámbitos rurales, gestión municipal y agenda de reformas', in Javier Torres Sedane, Romeo Grompone and Rodrigo Barrenechea Carpio (eds.), Los bases del gobierno local en el Perú (Lima: Instituto de Estudios Peruanos, 2008), Linda Seligmann, Between Reform and Revolution: Political Struggles in the Peruvian Andes, 1969-IggI (Stanford, CA: Stanford University Press, 1995); Paul Trawick, The Struggle for Water in Peru: Tragedy and Comedy in the Andean Commons (Stanford, CA: Stanford University Press, 2003); Paul Gelles, Water and Power in Highland Peru: The Cultural Politics of Irrigation and Development (New Brunswick, NJ: Rutgers University Press, 2000). 
that are legally unavailable to 'villages'. Although this upgrade, which the villagers were granted, gave the local government welcome access to a small budget, its real importance was in paving the way for the village to construct itself, politically and physically, as a sub-district with a local municipality building in addition to the physical structures of the plaza and the school, as well as light, water and other infrastructural benefits.

In Huancapampa mayors and national presidents alike are named 'father of the people' (padre del pueblo).7 Such as term implies certain imagined intimacy between the governed and government, a proximity that also entails the possibility of deceit. The idiom of abandonment harks back to profoundly Andean idioms of orphanage, and to the presence and absent presence of the state. ${ }^{8}$ It is firmly grounded in pre-existing Andean discourses that are continually reworked and deployed in new ways. 'The orphan', writes Leinaweaver, is not an orphaned child, but 'someone who has lost all the support of his or her family'.? The wakcha, meaning both 'poor' and 'orphan' in Quechua, is therefore not necessarily without kin, but abandoned; he or she is one without 'an adequate network of kin and compadres to supply the necessary reciprocal aid to function in comunero society'. ${ }^{\circ}$ Being poor, being orphaned, being forgotten and being abandoned are therefore closely related. This article explores how such an idiom of intimacy becomes part of local politics. There has been an increasing and long-standing presence of the state in this area in the form of military conscription, census, taxation, public health, schooling, land titling, infrastructure, veterinary and agricultural interventions, and others. ${ }^{11}$ Even so, the relationship to authorities is continuously and persistently figured as one of abandonment and forgetting. If the idiom of abandonment is not a representation of government presence in Huancapampa, what kind of work does it then perform? What kind of boundary between state and society is drawn by invoking such a notion? And what kind of citizenship is produced by these figurations?

7 See also Robert M. Levine, The History of Brazil (Westwork, CT, and London: Greenwood Press, 1999), pp. 106-7 for Brazil, where Vargas was called 'the father of the poor' in the I950s.

${ }^{8}$ Daniel M. Goldstein, 'Orphans of the State: Conceptualizing Citizenship, Space, and Kinship in Bolivian Municipal Politics', Cultural Dynamics, I7: I (2005), pp. 5-3 I; Daniel M. Goldstein, Outlawed: Between Security and Rights in a Bolivian City (Durham, NC: Duke University Press, 2012). Jessaca B. Leinaweaver, The Circulation of Children: Kinship, Adoption, and Morality in Andean Peru (Durham, NC: Duke University Press, 2008); Jaymie Heilman, Before the Shining Path: Politics in Rural Ayacucho, 1895-1980 (Palo Alto, CA: Stanford University Press, 2010).

9 Leinaweaver, The Circulation of Children, p. 75.

${ }^{1}$ Billie Jean Isbell, To Defend Ourselves: Ecology and Ritual in an Andean Village (Prospect Heights, IL: Waveland Press, 1985), p. 76.

${ }^{1}$ See also Frank Salomon and Mercedes Niño-Murcia, The Lettered Mountain: A Peruvian Village's Way with Writing (Durham, NC: Duke University Press, 20 I I), p. 69. 
Partha Chatterjee has described the ways that subalterns engage with power structures to which they are only partially connected as 'the politics of the governed'. ${ }^{12}$ In this article I build on an emerging body of literature concerned with the ways that both concrete state institutions and persons and imaginaries of the state permeate local politics. ${ }^{13}$ However, neither the materiality nor the imaginary or magical state exists independent of the other. They are the products of concrete encounters and distinct historical processes. ${ }^{14}$ As noted elsewhere, the daily material investments of the state maintain the fantasies of the state. ${ }^{15}$ The intimacy and affect that abandonment semantically carries with it disrupt neat separations between the material work and fantasies of state. Consequently, ideas about what the proper relationship between state and citizen should be and how these boundaries are drawn are part of the production of 'state effects' ${ }^{16}$

To Chatterjee, entanglements between elite and subaltern agendas in the politics of the governed concern not the normative ('formal') but the experienced ('real') citizenship. ${ }^{17}$ Here, rather than an absolute category, citizenship relates to particular, situated understandings of the relationship between government and the governed. I pick up this idea about the links between the local politics of the governed and the exercise of citizenship and local configurations of democracy. Citizens are bearers of rights. However, as Chatterjee notes,

Most of the inhabitants of India are only tenuously, and even then ambiguously and contextually, rights-bearing citizens in the sense imagined by the constitution. They are not, therefore, proper members of civil society and are not regarded as such by the institutions of the state. But it is not as though they are outside the reach of the state or even excluded from the domain of politics. As populations within the territorial jurisdiction of the state, they have to be both looked after and controlled by various government agencies. These activities bring these populations into a certain political relationship with the state. [...] Yet these are without doubt political relations that may have acquired, in specific historically defined contexts, a widely recognized systematic character, and perhaps even certain conventionally recognized ethical

${ }^{12}$ Partha Chatterjee, The Politics of the Governed: Reflections on Popular Politics in Most of the World (New York: Columbia University Press, 2004).

${ }^{13}$ Monique Nuijten, Power, Community and the State: The Political Anthropology of Organisation in Mexico (London and Sterling, VA: Pluto Press, 2003); Alpa Shah, "'Keeping the State Away": Democracy, Politics, and the State in India's Jharkhand', Journal of the Royal Anthropological Institute, I3: I (2007), pp. I 29-45.

${ }^{14}$ Timothy Mitchell, Rule of Experts: Egypt, Techno-Politics, Modernity (Berkeley, CA: University of California Press, 2002); 'The Limits of the State: Beyond Statist Approaches and Their Critics', American Political Science Review, 85: I (1991), pp. 77-96.

is See Yael Navaro-Yashin, Faces of the State: Secularism and Public Life in Turkey (Princeton, NJ: Princeton University Press, 2002).

${ }^{16}$ Mitchell, Limits of the State; Philip Abrams, 'Notes on the Difficulty of Studying the State', Journal of Historical Sociology, I: I (1988), pp. 58-89. See also Francisco Lewis Denegri, 'Efectos del estado como poder del estado: expectativas, ansiedad y temor en la Cuenca de Inambari, Anthropológica, 30 (2012), pp. 29-44.

${ }^{17}$ Chatterjee, 2004, pp. 4, 39-40. Chatterjee uses the notion of political society for understanding this entanglement. 


\section{Mattias Borg Rasmussen}

norms, even if subject to varying degrees of contestation. How are we to begin to understand these processes? ${ }^{18}$

In the politics of the governed, rights cannot be assumed. Subaltern groups must navigate their way through an uncertain political terrain through the establishment of connections with more privileged and influential groups. But to Chatterjee, the instrumental use of the vote, often cast as clientelism in Latin America, 'is possible only within a field of strategic politics'. ${ }^{\text {is }}$ In thinking with his poignant analysis I explore how we can understand the co-production of citizenship and state in highland Peru. As Martín Tanaka has argued, the rupture of the twentieth century oligarchic order with the inauguration of the military-revolutionary government of Velasco in 1968 did not create a new alternative, but left the Peruvian state in a profound legitimacy crisis. ${ }^{20}$ Since the establishment of the republic, and the construction of inclusive and equal citizenship as a legal category, citizenship across an uneven social terrain has been challenged by the persistence of ethnic difference in a deeply racialised society. ${ }^{21}$ Even with today's focus on interculturalism the main problem continues to be that 'in representative democracies, the public spheres and political parties are monocultural and exclusive of othernesses.' ${ }^{22}$

The focus on abandonment highlights the affective dimensions to citizenship. $^{23}$ Citizenship can be understood as a bundle of practices between people and structures of power. ${ }^{24}$ It entails the relationship between individuals (sometimes groups) and institutions of public authority. ${ }^{25}$

${ }_{18}$ Chatterjee, Politics of the Governed, p. 30.

19 Ibid., p. 40.

${ }^{20}$ Martín Tanaka, 'Las relaciones entre estado y sociedad en el Perú: desestructuración sin reestructuración. Un ensayo bibliográfico', America Latina Hoy, 3 I (2002), pp. I89-2 I 8; see also the classic work by Julio Cotler, Clases, estado y nación (Lima, Instituto de Estudios Peruanos, 3 ra edición, 2005), especially chap. 7.

${ }^{21}$ Marisol de la Cadena, Indigenas mestizas: raza y cultura en el Cusco (Lima: Instituto de Estudios Peruanos, 2004); Mark Thurner, " "Republicanos" and "la comunidad de peruanos": Unimagined Political Communities in Postcolonial Andean Peru', Journal of Latin American Studies 27 (1995), pp. 291-318.

${ }^{22}$ Fidel Tubino, 'No uno sino muchas ciudadanías: una reflexión desde el Perú y Ámerica Latina', Construyendo Nuestra Interculturalidad, 5: 4 (2009), pp. I-13. My translation, p. ı. See also Nila Vigil and Roberto Zariquiey (eds.), Ciudadanías inconclusas. El ejercicio de los derechos en las sociedades asimétricas (Lima: GTZ and Pontificia Universidad Católica del Perú, 2003).

${ }^{23}$ See also Sian Lazar, 'Personalist Politics, Clientelism and Citizenship: Local Elections in El Alto, Bolivia', Bulletin of Latin American Research, 23: 2 (2004), pp. 228-43; Monique Nuijten, "The Perversity of the "Citizenship Game": Slum-upgrading in the Urban Periphery of Recife, Brazil', Critique of Anthropology, 33: I (2013), pp. 8-25; Sian Lazar and Monique Nuijten, 'Citizenship, the Self, and Political Agency', Critique of Anthropology, 33: I (2013), pp. 3-7.

${ }^{24}$ Sian Lazar, El Alto, Rebel City: Self and Citizenship in Andean Bolivia (Durham, NC: Duke University Press, 2008).

${ }^{25}$ James Holston, 'Contesting Privilege with Right: The Transformation of Differentiated Citizenship in Brazil', Citizenship Studies, I 5: 3-4 (201 I), pp. 335-52. 
Claims to rights and citizenship constitute political subjects who demand recognition and critique practices that reproduce inequalities and exclusion. ${ }^{26}$ Citizenship therefore evokes not only claims and rights, but also feelings of belonging to town, province and nation. ${ }^{27}$ Ideally, the opinions of effective (remembered) citizens do matter to the state; by critiquing governance, the villagers perform their (hopeful) citizenship. Rather than bringing clientelism and citizenship in opposition, the case here shows how in establishing social relations through exchanges, which may be termed clientelistic, the villagers of Huancapampa are practising particular modalities of citizenship; that is, understandings of these practices of belonging rooted in what Rosaldo termed 'vernaculars of citizenship'. ${ }^{28}$ Claims to rights (who has them, what constitutes them, who is responsible for them) provide a conceptual horizon for political practices, actions and words, thereby directing our attention to how such claims are linked to individual and collective projects, needs and desires. ${ }^{29}$ Rather than a strictly legal category, this kind of affective citizenship entails intimacy and reciprocity. The study thereby contributes to a growing body of literature challenging modern liberal assumptions with regard to citizenship in Latin America. ${ }^{30}$

The material presented in this article was gathered through 12 months of fieldwork between 2010 and $201 \mathrm{I}$, as well as short visits in 2013, 2014 and 2015, where I followed four different villages, interconnected by waterways and a range of other social relations in their collective endeavours to secure water. ${ }^{31}$ This article relies particularly on interviews and participant observation in meetings at the village level as well as those in the comunidad campesina (small peasant community) controlling the upper territories of Huancapampa. I conducted 55 semi-structured interviews, a household survey, GPS mappings of waterways and sources, a series of conversation walks in the terrain, and an uncounted number of informal conversations in the four villages and the Recuay municipality.

${ }^{26}$ Evelyn Dagnino, 'Citizenship in Latin America: An Introduction', Latin American Perspectives, 30: 2 (2003), pp. 3-17.

${ }^{27}$ Fiona Wilson, Citizenship and Political Violence in Peru: An Andean Town, 1870s-1970s (New York: Palgrave Macmillan, 2013).

${ }^{28}$ Sian Lazar, Personalist Politics, Clientelism and Citizenship; Renato Rosaldo, 'Cultural Citizenship and Educational Democracy', in Cultural Anthropology, 9: 3 (1 994), pp. 402-1 I.

${ }^{29}$ Julia Eckert, 'Introduction: Subjects of Citizenship', Citizenship Studies I 5.3-4 (20 I I), pp. 309-17.

${ }^{30}$ See Judy Meltzer and Cristina Rojas, 'Narratives and Imaginaries of Citizenship in Latin America', Citizenship Studies, 17: 5 (2013), pp. 525-9, and the collection in Citizenship Studies that they introduce.

${ }^{31}$ Mattias Borg Rasmussen, Andean Waterways: Resource Politics in Highland Peru (Seattle, WA: University of Washington Press, 2015). 


\section{Developing Huancapampa: Local Politics of Progress}

If you cross the Velasco Bridge, which connects Recuay to the eastern shores of the River Santa, a green signpost leaning slightly towards the right will inform you that you are entering Huancapampa. Most of the houses are adobe constructions amidst a few concrete buildings and the modern concrete square. A mint-green school building dominates the village, but the school serves only a few of the village's children. The rest of them walk across the bridge to Recuay. Dotting the streets in Huancapampa proper are a handful of waste bins with the notice 'Huancapampa - te queremos limpia' (Huancapampa we want you to be clean). When I came back to Huancapampa in 2014, a new concrete building had emerged: a red-brick, one-storey municipality building. This article traces its appearance.

At the village meetings in Huancapampa, residents continuously express deeply felt concerns regarding the development of the community and what should be present for the cluster of houses to count as a village; that is, as a liveable space recognised by higher level authorities. Huancapampa is a small village of approximately 70 households distributed in Huancapampa proper and Aconan, also known as the barrio arriba, or upper neighbourhood. Behind Huancapampa, the slopes are steep, and a winding ascent of 30 to 45 minutes will lead the visitor to the villages located further uphill on the limits of the highland grassland area known locally as the puna. In Huancapampa, people are small-holders and were so before the 1969 agrarian reform, but many are also members of a comunidad campesina and therefore have access to communal lands. People in the upper villages tend to rely on their own production for their sustenance, while people in Huancapampa are more likely to take salaried work. All, however, are thoroughly involved in the market economy. ${ }^{32}$ While the older people speak predominantly Quechua, younger generations (those under the age of 60) tend to use Spanish as their vernacular. This is even more the case in political arenas such as those discussed in this article.

The encounters that I describe here occur between different political structures overlapping spatially and jurisdictionally. Settlements are organised in a nested hierarchy of districts, provinces and regions which are all subject to democratic elections. On the local level, a populated settlement (centro poblado) may also have a number of smaller hamlets under its jurisdiction. In the case of Huancapampa, these hamlets are Ocopampa and Shecllapata. The minor settlements (Huancapampa, Ocopampa and Shecllapata) have a dual political leadership. The alcalde (in the case of Huancapampa) or

32 See Mattias Borg Rasmussen, 'Greening the Economy: Articulation and the Problem of Governance in Highland Peru', Mountain Research and Development, 32: 2 (2012), pp. $149-57$. 
the agente municipal (in the case of Ocopampa) is elected by a village assembly. These work in tandem with upper-level municipalities in Recuay and Ticapampa. The teniente gobernador is appointed by an assembly, and is (officially) answerable directly to the presidency in Lima. These act as juridical authority in small matters which do not need the attention of the fiscal attorney in Recuay.

Community-based institutions are formed to address particular issues, such as schooling, water and waste. Ideally, their activities should be coordinated with the local municipality, including the Recuay mayor's office. Apart from the potable water and sewage commission, Juntas Administradoras de Servicio y Saneamento (Administrative Juntas of Services and Sewage, JASS), in Huancapampa these institutions are all headed by women. Thus, while formal political spheres such as the municipalities I deal with here are dominated by men, many of the everyday affairs concerning village welfare and improvement are taken up by (or left to) organisations led by women. Affairs regarding the domestic spheres and domestication of the public spheres through sanitation and education are led mainly by women. While so far men have been reluctant to give up formal power within the village structure, there is a growing acknowledgement that 'women are also capable' and, in fact, highly efficient in terms of getting things done in collaboration with the Recuay municipality, to some extent, and with the local NGOs to a greater extent.

Parallel to this state-sponsored hierarchy of territorial governance exist the comunidades campesinas. Regulated by the law of peasant communities, these are semi-autonomous organisations based on common ownership of the land and collective production. Historically, due to the centrality of territories, the ways in which these have been ruled by local elites and the long-standing struggles for autonomy, as political institutions the comunidades campesinas that I have worked with have had closer encounters with central government than have the small-holders in Huancapampa. In the case of the hinterlands of Huancapampa, the comunidad campesina Los Andes de Recuay spans a territory which belongs both to the jurisdictions of Recuay (as district and province), Ticapampa (as district) and as of recently, to Huancapampa (as centro poblado menor).

The Huancapampinos also refer to the regional government of Ancash and the national government of Peru as well as to the attendant administrative institutions of these entities. This is so especially in the case of water and rural properties. It is therefore a complicated institutional territory that the villagers must learn to navigate. Each institution, shifting in competencies and structure as they regularly are, have their own bureaucratic logic. Rarely coinciding in priorities, government institutions attend to different matters of rural life, and communities can therefore put forward several claims simultaneously, but must also know that the terms of engagement differ between institutions. 


\section{Mattias Borg Rasmussen}

The state has a material presence in Huancapampa through the concrete outcomes of local governance manifest in the form of roads, schools, lamp posts and irrigation projects, as well as latrines and improved kitchens. None of these infrastructural achievements is purely the result of government intervention, benevolence or policies; rather, they are outcomes of a series of encounters, both consonant and disjunctive, between a great variety of state institutions and village politicians, leaders and commoners. So how can local development be designed in a way that makes local communities prosper? Wilson highlights the tensions inherent to discussions and processes of 'development' in the rural Andes. ${ }^{33}$ While the roads are ambiguous, bringing with them both connectivity and new forms of penetration, authors note the ubiquity of cement in local development projects as the most tangible and, indeed, concrete outcome of successful government. ${ }^{34}$

'This is the construction of development', the mayor of Recuay said, pointing at a newly inaugurated reservoir in Ocopampa. ${ }^{35}$ Indeed, much of local politics revolves around control of local infrastructure and external development interventions. ${ }^{36}$ This case entails particular entanglements and new configurations of municipal politics. It concerns visions of development related to infrastructure, here the construction of a municipality building in Huancapampa, and a long history of lack of presence by the central government in local affairs. In that regard, discussing how ethnographers should go about studying the state, Penny Harvey argues that the challenge is 'to identify material traces which can be engaged ethnographically and which open up, rather than close down, further perspectives on the structures and practices through which this particular mode of power is effected and reproduced'. ${ }^{37}$ The emergence of infrastructure and its attendant symbolic importance highlight the specific interface between state and people in encounters over the development

33 Fiona Wilson, 'Towards a Political Economy of Roads: Experiences from Peru', Development and Change, 35: 3 (2004), pp. 525-46.

34 John D. Cameron, "'Development Is a Bag of Cement": The Infrapolitics of Participatory Budgeting in the Andes', Development in Practice, 19: 6 (2009), pp. 692-701; Penny Harvey, 'Cementing Relations: The Materiality of Roads and Public Spaces in Provincial Peru', Social Analysis, 54: 2 (2010), pp. 28-46; Penny Harvey and Hannah Knox, “'Otherwise Engaged": Culture, Deviance and the Quest for Connectivity through Road Construction', Journal of Cultural Economy, I: I (2008), pp. 79-92; Hannah Knox and Penny Harvey, 'Anticipating Harm: Regulation and Irregularity on a Road Construction Project in the Peruvian Andes', Theory, Culture \& Society, 28: 6 (201 I), pp. 142-63; Michael Taussig, 'Cement and Speed', in My Cocaine Museum (Chicago: University of Chicago Press, 2004), pp. 1 59-70.

${ }^{35}$ Field notes, I September 20 io.

${ }^{36}$ John D. Cameron, 'Hacia la alcaldia: The Municipalization of Peasant Politics in the Andes', Latin American Perspectives, $36: 4$ (2009), p. 70.

37 Penelope Harvey, 'The Materiality of State-Effects: An Ethnography of a Road in the Peruvian Andes', in Christian Krohn-Hansen and Knut G. Nustad (eds.), State Formation: Anthropological Perspectives (London and Ann Arbor, MI: Pluto Press, 2005), p. I 24 . 
of Huancapampa, consequently, the ways in which the state, campesinos and other actors may seek to control local affairs.

\section{Dealing with the Arbitrary: Frustrated State Encounters}

Life in the rural hinterland of Recuay is characterised by the erratic presence of justice, a fragile physical infrastructure, spatial and symbolic distance from central sites of power and a legacy of internal exploitation and negligence. In many ways the current Andean context echoes Goldstein's description of life in the urban margins of Cochabamba, Bolivia, and what he calls the 'phantom state', highlighting the spectral qualities of a state apparatus which is 'both there and not there; people can feel at once burdened and abandoned by the state, simultaneously oppressed and ignored'. ${ }^{38}$ However, the apparent absence of the state is not synonymous with non-presence. Instead, the state apparatus, here understood as federal, regional and municipal governments, operates in particular ways on the margins of its own domain.

As described, the authority to govern space and people in Recuay is claimed by a variety of political institutions. While Huancapampa formally has a peasant patrol (ronda campesina) to resolve social problems (cattle-rustling in particular), this local law-enforcement institution was not operating during my stay. Locally, Huancapampa is known as la cuna de los abigeos, or 'cradle of the cattle-rustlers'. Incidents of cattle-rustling are indicative of a situation in which the government is unable to guarantee the security of its citizens and their property. As result, other forms of state-like entities, such as the peasant patrols, emerge. ${ }^{39}$ The sense of insecurity and a generalised mistrust not only of strangers but also of other villagers is an important aspect of how people interact with state agencies. These attitudes figure into people's calculations of injustice and impunity and also, crucially, shape the dynamics of internal village politics.

Consider this story told by Don Lucas, a former president of the peasant community subsector in Shecllapata. It had long been a dream to bring water from the high altitudes to the plateau at Shecllapata, one of the hamlets belonging to Huancapampa. After continued visits to the regional government of Ancash in Huaraz, Don Lucas had finally persuaded a water engineer to come to Shecllapata. He would have to pay his expenses and lunch but calculated that the possible gains of the project outweighed the

${ }^{38}$ Goldstein, Outlawed, p. 83.

39 See John S. Gitlitz, Administrando justicia al margen del estado: las rondas campesinas de Cajamarca (Lima: IEP, 2009); Deborah Poole, 'Landscapes of Power in a Cattle-Rustling Culture of Southern Andean Peru', Dialectical Anthropology, I2: 4 (1987), pp. 367-98; Orin Starn, Nightwatch: The Politics of Protest in the Andes (Durham, NC: Duke University Press, 1999). 


\section{Mattias Borg Rasmussen}

immediate costs. The engineer had come in March, so when they reached the River Atoq Huacanca, which has to be to crossed to get from Huancapampa to Shecllapata, there was too much water in it. Don Lucas took off his trousers, as he is used to, but the engineer refused. They tried to get a ladder for the Huaraz personnel to cross the river, but ultimately they failed, and the expedition towards Shecllapata was aborted. Don Lucas continues:

Then this señor Segundo Aguilar tells us that we have to organise ourselves, and then we will talk. But until now he hasn't come back. And he doesn't answer. He doesn't answer. He offered to come, and when I call - here's his number [Don Lucas shows me a page in his little notebook.] - he says that week, that week, that week. He continues like it is a game. He keeps postponing it like it is a deception, like we are little children to deceive. Your candy, we will bring it to you if you sit still without crying. It's the same. I think that he came here just to campaign. It was a year ago, and since then we have not seen him. But I told him, in that moment when we were trying to cross the water of Atoq Huancanca, that he had to bring the message to the regional president that no authority pays attention to us. It is hard to make them pay attention to us, but easy to make them come and make us vote for them. Promises, promises, we are tired of promises. ${ }^{\circ}$

Here the paternalistic relationship between Don Lucas and the state official is quite clear. So is the idiom of abandonment behind it. In Huancapampa, the problem regarding encounters with state officials is not absence, but rather arbitrariness. To the Huancapampinos, the state is not perceived or encountered as a unity, but as very different persons and institutions, each possessing different abilities to get things done. Experiences in the area of law enforcement and the patterns of corruption on either side of the law related to enduring problems of cattle-rustling and social insecurity are reflected in other arenas of local engagement with state authorities: long waits at the municipality building and abusive language once you are admitted, the need to buy lunch and pay transport expenses, and, more often than not, futile encounters and even the failure to show up. The abusive arbitrariness of attention compounds to nurturing the sense of abandonment.

The villagers have to deal with authorities working with opaque agendas. The experience with individual officials is linked to wider government concerns with rural life and livelihoods. At a meeting in the comunidad campesina discussing the implications of the 2009 water law on local water distribution, one of the participants noted: 'This law is made for the coast. Not for us.' This was both a matter-of-fact statement with regard to the scope of the law and a critical comment on the reach and ambitions of the law. As Peruvian sociologist María Isabel Remy has noted with regard to participatory mechanisms, these cover a wide array of possible encounters between communities and state entities. Each of these entails different realities and leads to different

${ }^{40}$ Interview with Don Lucas, in Recuay, 2 I Aug. 2010. 
effects and development trajectories. ${ }^{41}$ Before moving into the concrete encounters over the development of Huancapampa, I therefore turn to the question of how to understand the co-constitution of state and society in the Peruvian context.

\section{State, Government and the Politics of Abandonment}

In Huancapampa two presidents are fondly remembered. The first is Juan Velasco Alvarado, the revolutionary-military president who seized power from Fernando Belaúnde Terry in 1968, promulgated the long-awaited land reform in 1969, and rebuilt the region of Ancash after the 1970 earthquake. Second, Alberto Fujimori, who in the r 990 os defeated Sendero Luminoso (the Shining Path) and put up numerous concrete structures painted in bright orange. ${ }^{42}$ In different ways, these were presidents who are remembered as being close to people. Doña Antonia told me about the landing of Fujimori's helicopter just across the river in the early i990s, when Sendero Luminoso activities had been halted in the area. Huge crowds gathered to receive the president. Doña Antonia called for him, thanked him and received a hug. When Doña Antonia told me this story, we were talking about how the central government fails to deliver: 'Now, they have forgotten about us', Doña Antonia said. On another occasion, her cousin Doña Julia also noted the absence of 'Señor Government':

We greatly need to increase our [agricultural] production. But today the state, the government, they say that they will help us, the poor people. But there is no support. At least the government with its mining revenues [canon minero] has a lot of money. Ay, we have so much money, the people of Ancash have money, gold. But with this money, who gets rich? We, the people of the countryside, we struggle; we struggle, and there is no support. ${ }^{43}$

Echoing the above-mentioned statement on water legislation, Doña Julia here addresses the absence of concern for rural livelihoods in practice. New patterns of governance have revealed the plundering of the Andean countryside. ${ }^{44}$ To Doña Julia, government is no longer a matter of politics. Academic scholarship has described the Peruvian state as being in the hands of both technocrats and

${ }^{41}$ María Isabel Remy, Los múltiples campos de la participación ciudadana en el Perú: un reconocimiento del terreno y algunas reflexiones (Lima: IEP, 2005).

${ }^{42}$ For studies on populism in Peru, see for example Steve Ellner, 'The Contrasting Variants of the Populism of Hugo Chávez and Alberto Fujimori', Journal of Latin American Studies, 35 : I (2003), pp. 139-62; Robert R. Barr, 'The Persistence of Neopopulism in Peru? From Fujimori to Toledo', Third World Quarterly, 24: 6 (2003), pp. I I61-78.

${ }^{43}$ Interview with Doña Antonia, in Poccrac, 17 Sept. 2010.

${ }^{44}$ See Mattias Borg Rasmussen, 'Reclaiming the Lake: Citizenship and Environment-asCommon-Property in Highland Peru', Focaal, 74 (2016), pp. 13-27. 
business. ${ }^{45}$ Regional political movements have dominated lower levels of government, and at the time of this writing, only a few of the regional governments are headed by a traditional political party. ${ }^{46}$ Relating to the coproduction of state and society, these processes attain effect in the encounters over local development. ${ }^{47}$ It is in the concrete everyday interactions between different kinds of institutions that whatever the state is comes into being. But these interactions attain their particular meaning only because they relate to ideas of what the state is and should be. Thus, the state is not a given, pre-existing entity which uniformly governs across the terrain. It makes no sense to establish a neat separation between the state as an idea and the state as a physical entity. ${ }^{8}$ These are intimately related. The distinctions between what counts as state and what counts as society are therefore described as the uncertain outcome of historical processes. ${ }^{49}$ There is a historical contingency to the ways in which the state as ideas, visions, technologies, concrete encounters, and materialities becomes part of local politics.

In the co-production of state and citizenship, abandonment is a key trope for understanding how the villagers draw upon a historically contingent experience of the state. The central Peruvian government has historically exerted an unstable presence in the provinces, giving rise to local struggles for power and legitimacy. ${ }^{\circ}$ Even so, historically there has also been reciprocity between the central state and the peasant communities, for example in terms of land-forlabour. ${ }^{5}$ The existence of reciprocal expectations between the central government and local communities highlights the deeply personalistic character of formal politics in Andean Peru and the different strategies through which villagers seek to gain access to those in power. Indeed, exclusions and partial

45 Eduardo Dargent, Technocracy and Democracy in Latin America: The Experts Running Government (Cambridge; Cambridge University Press, 2012); Francisco Durand, 'Empresarios a la presidencia', Nueva Sociedad, 225 (2010), pp. 68-85.

${ }^{46}$ See, for example, Maria Isabel Remy, 'Los gobiernos locales en el Perú: entre el entusiasmo democrático y el deterioro de la representación política', in Victor Vich (ed.), El Estado está de vuelta: desigualdad, diversidad y democracia (Lima: IEP, 2005), pp. i I I-36.; Martín Tanaka (ed.), El Estado, viejo desconocido: visiones del estado en el Perú (Lima: IEP, 2010).

${ }^{47}$ David Nugent, Modernity at the Edge of Empire: State, Individual, and Nation in the Northern Peruvian Andes, 1885-1935 (Stanford, CA: Stanford University Press, 1997); 'Before History and Prior to Politics: Time, Space, and Territory in the Modern Peruvian Nation-State', in Hansen and Stepputat (eds.), States of Imagination, pp. 257--83; 'States, Secrecy, Subversives: APRA and Political Fantasy in mid-2oth-Century Peru', American Ethnologist, 37: 4 (2010), pp. 68 1-702.

${ }^{8}$ Mitchell, Limits of the State; Rule of Experts.

49 Ibid., p. 74.

so Deborah Poole, 'Between Threat and Guarantee: Justice and Community in the Margins of the Peruvian State', in Veena Das and Deborah Poole (eds.), Anthropology in the Margins of the State (Santa Fe, NM: School of American Research Press, 2004), pp. 35-65.

${ }^{51}$ Fiona Wilson, 'Reconfiguring the Indian: Land-Labour Relations in the Postcolonial Andes', Journal of Latin American Studies, 35: 2 (2003), pp. 22 I-47; Tristan Platt, Estado boliviano y ayllu andino. Tierra y tributo en el norte de Potosi (Lima: IEP, 1982). 
incorporation, the dynamics of coercion and consent, and contentious ideas about nation and citizenship were fundamental in legitimising postcolonial state formation. ${ }^{52}$ The legacies of the interpenetration of state formation and local politics are enduring, and projects of state formation have deeply influenced local affairs in different periods ranging from early rebellions against the republic through racialised labour policies and the production of local political orders. ${ }^{53}$ When Velasco ousted Belaúnde in 1968, it arguably created an rupture with the oligarchic state, and the decades that followed with the 1969 agrarian reform and the militant insurgency of Sendero Luminoso in the I980s into the first half of the r 990 s were marked by what Tanaka calls 'destructuring without restructuring'. ${ }^{54} \mathrm{I}$ will focus on that next before turning to more recent attempts of such reconfigurations of regional politics.

The combination of the agrarian reform and the presence of Sendero Luminoso changed the ways in which both community and state were imagined and how the latter was called upon in the rural Andes. Linda Seligmann finds that the agrarian reform created shifts in the power balance between the landed elite, the state and the peasant in which the latter gained unprecedented access to local political-legal institutions. ${ }^{55}$ The qualitative shift in state-peasant relations opened up new local dynamics of influence in which peasants sought to take advantage of the available political space through both old and new institutional arrangements, opting for more subtle forms of resistance through political and legal means, creating 'sufficient political leverage to shift their relationship in the state in their favor'. ${ }^{6}$ In rural Ayacucho, peasants mobilise the concept of abandonment to describe their political condition in the twentieth century, implying a form of 'governance that operates on a principle of intentional and detrimental neglect instead of dominance or hegemony and that reinforces state rule through sporadic bursts of punitive violence'. ${ }^{57}$ Rooted in historical experience abandonment is 'an imperfect term, as it necessarily implies an earlier historical moment when the state acknowledged, remembered, and tended

52 Florencia Mallon, Peasant and Nation: The Making of Postcolonial Peru and Mexico (Berkeley, CA and London: University of California Press, 1995).

${ }_{53}$ For nineteenth century rebellions, see Mark Thurner, From Two Republics to One Divided: Contradictions of Postcolonial Nationmaking in Andean Peru (Durham, NC: Duke University Press, 1997), Cecilia Méndez, The Plebeian Republic: The Huanta Rebellion and the Making of the Peruvian State, 1820-1850 (Durham, NC: Duke University Press, 2005); for early twentieth century labour policies, see Paulo Drinot, The Allure of Labor: Workers, Race and the Making of the Peruvian State (Durham, NC: Duke University Press, 20 I I); for local political struggles, see Wilson, Citizenship and Political Violence; Nugent, Modernity at the Edge.

${ }_{54}$ Tanaka, Relaciones entre estado y sociedad.

ss Seligmann, Between Reform and Revolution.

${ }^{56}$ Ibid., p. Iо.

${ }^{57}$ Heilman, Before the Shining Path, p. Io. 


\section{Mattias Borg Rasmussen}

to now-orphaned regions'.$^{8}$ In this, there is a relation between state acknowledgement, remembrance, forgetting and the idea of 'the orphan' deeply rooted in Andean imaginaries. ${ }^{59}$

Towards the end of the i 980 s, the political system collapsed because of the severe economic and social crisis. Broadly speaking, formal political parties were dismantled and replaced in regional politics by mushrooming political movements, hampering the establishment of durable links between state and society. ${ }^{60}$ With the election of Fujimori in 1990 , Peruvians everywhere, but especially in urban areas, had sought an alternative to 'establishment' politics. But Fujimori's election had also important effects in rural areas. Through his 'direct democracy' approach, the national government was suddenly a real presence in even the most remote of villages; the application there of methods and systems devised at the national level led to the dissolution or erasure of important pre-existing local institutions and social programmes. ${ }^{6}$ The social programmes instituted under Fujimori further eroded the legitimacy of local government. ${ }^{62}$ Since the turn of the century, the emphasis on local participation and decentralisation of political structures has resituated municipalities and their governance at the centre, because these are supposedly more democratic, and more capable of effectively addressing local issues. ${ }^{63}$

The recent surge in decentralisation and regionalism has created a new situation in many places, where local communities and municipalities have been fighting intensely over these new spaces for participation, governance and financial resources. In practice, these democratic expectations were deceived and democratic decentralisation led to a number of violent conflicts around the allocation and management of public goods. The profound institutional changes such as decentralisation, agrarian reforms and the canon minero were accompanied by demographic changes: descendants of former landruling elites either competed for power with peasants or simply left the countryside, leaving behind a political space that was left to people of lower social standing whose ethnic affiliations had historically been denigrated. ${ }^{64}$ Conflicts

${ }^{58}$ Ibid.

59 The nature of forgetting is highlighted by Ben Orlove, Lines in the Water: Nature and Culture at Lake Titicaca (Berkeley, CA: University of California Press, 2002); the orphan discussed by Goldstein, 'Orphans of the State'; and Leinaweaver, The Circulation of Children.

${ }^{60}$ John Crabtree, 'Democracy without Parties? Some Lessons from Peru', Journal of Latin American Studies, 42: 2 (2010), pp. 357-82.

${ }^{61}$ Martín Tanaka and Trivelli Carolina, 'Las trampas de la focalización y la participación: pobreza y políticas sociales en el Perú durante la década de Fujimori', Socialis: reflexiones latinoamericanas sobre politica social, vol. 5, noviembre (Rosario, Argentina: Homosapiens Ediciones, 200I).

${ }^{62}$ Remy, Gobiernos locales en el Perú.

${ }^{63}$ John D. Cameron, Struggles for Local Democracy in the Andes (Boulder, CO, and London: First Forum Press, 2010).

${ }^{64}$ Remy, Gobiernos locales, p. i i6; Cameron, 'Hacia la alcaldía'. 
between mayors and rural residents increased during the i 990 s. In April 2004 the mayor of Ilave in southern Peru was lynched after a long period of public discontent and disputes concerning municipal power. ${ }^{65}$ Likewise, the 2004-06 conflict between the Pucará municipality and local communities was attributed to disputes over access to and the discretional management of public resources. ${ }^{66}$

Currently, the figuration of abandonment feeds into a situation in which more than two decades of neoliberal economic reform and a recent prolonged boom in extractive industries have brought both economic growth and, especially during the last decade, an increase in environmental conflicts. ${ }^{67}$ These are highly contradictory processes which create both nice macroeconomic figures and yet, in places such as Huancapampa, a sense of being spectators of rather than participants in development. Through procedures outlined in the 2002 canon minero, a portion of the mining tax paid by transnational mining companies must go to affected villages and towns. ${ }^{68}$ Some municipal districts therefore receive more income than others. ${ }^{69}$ During meetings where infrastructure was discussed, it would sometimes be noted that the mayor was 'sitting on gold' $7^{\circ}$ People's feelings seemed to be that, while there was money in provincial municipalities, it was not being put to use to the benefit of the rural folks. Some municipalities therefore have abundant public funds for which there is no clear use-plan, and in Ancash corruption is currently a major issue.

I look further into these conditions for local government in the next-butone section as we now turn to the manoeuvres in Huancapampa.

\section{Imagining Huancapampa: The Politics of Influence}

With this important backdrop against which local politics are played out, we now turn to the political manoeuvres that would eventually lead to the recognition of Huancapampa as a centro poblado menor..$^{71}$ Talks had been ongoing for some time and were ignited when nearby the Collahuasi village got its recognition and two-storey municipal building. One event in particular seemed to set things in motion in Huancapampa, when the meeting of the participatory

${ }^{65}$ Ramon Pajuelo, No hay ley para nosotros (Lima: IEP, 2009). Carlos Iván Degregori, Ilave: desafio de la gobernabilidad, la democracia participativa y la descentralización (Lima: Grupo Propuesta Ciudadana, 2004).

${ }^{66}$ Juan Luis Dammert Bello, 'El conflicto municipal en Pucará, Puno (2004-06)', in Tanaka (ed.), Estado, viejo desconocido, pp. 235-300.

${ }^{67}$ Javier Arellano-Yanguas, 'Mining and Conflict in Peru: Sowing the Minerals, Reaping a Hail of Stones', in Anthony Bebbington (ed.), Social Conflict, Economic Development and the Extractive Industry: Evidence from South America (London: Routledge, 2012).

${ }^{68}$ Ministry Resolution No. 266-2002-EF/15 of May I.

${ }^{69}$ Javier Arellano-Yanguas, 'Aggravating the Resource Curse: Decentralisation, Mining, and Conflict in Peru', Journal of Development Studies 47: 4 (201 I), pp. 617-38.

${ }^{70}$ See Rasmussen, Andean Waterways, chap. 4.

${ }^{71}$ The following is based on field notes, 7 June 2010. 


\section{Mattias Borg Rasmussen}

budget, orchestrated by a local NGO, became the trigger of the Recuay mayor's electoral campaign. Members of the community-based institutions of Huancapampa had gathered in one of the school's classrooms to discuss which projects to present to the municipality at the participatory budget meeting. When the village mayor appeared, accompanied by Milton León, the mayor of Recuay, the character of the meeting changed. Election season had begun, and Milton evidently saw this meeting as an opportunity to launch his campaign. Disregarding the NGO representative's neat charts, he promised to initiate the transfer of both funding and decision-making power to Huancapampa, including the construction of improved kitchens, and promised that his municipal technicians would look into issues of water supply and drainage. So, Huancapampa would at last become, as many villagers wanted, a municipality.

The Huancapampinos appeared thrilled at having gained so much from the meeting, and both the mayor and I were invited to Don Isidoro's place, where beer was sold. The actors changed: the meeting in the school had been dominated by the women leaders of the community-based institutions, but gradually they were outnumbered by men. The politics shifted sphere as the mayor came on stage. Local politics is often based on a very direct form of reciprocity: votes are never free, and Milton was hoping to secure quite a few by turning up in Huancapampa on this day, when he knew that many important people would be discussing the budget proposals. The villagers of Huancapampa were eager to take advantage of their exclusive access to the mayor, and, being both a village authority (teniente gobernador) and a businessman, Don Isidoro was happy to keep the beers flowing. At one point, Milton stepped away to relieve himself. In his absence, Pompeyo, the president of the JASS, and in line to become future mayor of Huancapampa, leaned towards the then vice-mayor Nelson. 'He must make more promises', Pompeyo said, pulling out an S/. Ioo note (US\$ 35) from his pocket to order yet another crate of beer. Even though Pompeyo is comparatively well off, supporting himself through construction work in Recuay and elsewhere, S/. Ioo represents a huge amount of the monthly household budget. But, as his nod seemed to indicate, it was money well spent.

The considerable size of the note that moved that night from Pompeyo's pockets to Don Isidoro's coffers in order to smooth things out with the Recuay mayor indicates a particular relationship between the villagers of Huancapampa and the politically elected authorities representing the state. Villagers will readily spend money that they can ill afford if it can help them to establish a personal link to a politician, even if that link is in its very nature tenuous and fragile. Recall Don Lucas' frustration after the failed attempt to cross Atoq Huancanca with the engineers from the regional government: 'We are tired of promises.' Why does Pompeyo then insist on the 
importance of promise? Why is it so important that he will even make a substantial contribution from his own meagre household budget? Don Lucas was tired of the deceit, tired of being treated like a little child. To make people wait, Auyero reminds us from Argentina's welfare offices, is a silent and efficient means of turning citizens into clients. ${ }^{72}$ To insist on drinking, however, is a way of creating intimate ties to those who hold power. ${ }^{73}$ The intimacy of the situation is therefore very different from the distant promises that Don Lucas referred to. The mayor was also interested in this interaction, showing his knowledge about the sociality of local patterns of consumption by sharing one single glass, emptying the glass in one, and pouring the remains on the hardened dirt floor. Sharing beers, and even more so maize beer (chicha), as occasionally happens, is a way of recognising the presence of Huancapampa and remembering its people.

But both Don Isidoro and Pompeyo are themselves part of the state-sponsored hierarchy. Being teniente gobernador, Don Isidoro is the official representative of the Peruvian president in the village, which grants him the authority to act as arbitrator in minor cases. Pompeyo is president of the JASS, a grass-roots organisation whose legitimacy depends on state recognition. Also, Nelson was eagerly passing opened beer bottles to the visiting mayor. By plying the mayor with drinks, Nelson was actively engaging with the mayor, strengthening their relationship, and hoping to protect his own new association with the state as the recognition would enhance his capacity to make requests, as well as increasing his budgetary powers.

The events described suggest that local configurations of authority in Huancapampa and its adjacent villages depend on their ability to correctly identify the degree to which a higher-order government institution may gain influence locally. The capacity to elicit care from the state, to be meaningfully 'remembered' rather than consigned to 'abandonment', is crucial to any village's success. As shown above, the peasants of Huancapampa succeeded in being 'remembered' (or at least in lessening their degree of 'abandonment') by the state, when Huancapampa's petition to become an urban centro poblado menor was approved. They now have greater access to funding and further signs of being a 'proper' village, such as: having a school, electricity in public spaces, a plaza, and churches, and now, having acceded to the status of 'municipality'. Clear 'development' of this kind requires village authorities and other local political actors to create the conditions for engaging with state officials.

Neither state nor citizen are independent of each other. They are relational entities that come into being, and continue to meaningfully obtain, only by

72 Javier Auyero, Patients of the State: The Politics of Waiting in Argentina (Durham, NC: Duke University Press, 2012).

${ }^{73}$ As noted by, for example, Poole, Landscapes of Power, p. 372. 


\section{Mattias Borg Rasmussen}

virtue of the other. The shapes and outcomes of these engagements (whether successful or not) are the raw material for the state's concrete effects, as well as the nature of the state in local imaginaries. Rural or marginal citizens cannot understand themselves or their position in relation to their own and other villages without engaging with and granting meaningful power to the idea of 'the state' that emerges in the encounters with different state officials and the promises of different things that these entail. Even when these result in disappointment such as that expressed by Don Lucas: to him, the state officials are strategically positioned in powerful networks with access to crucial resources.

The social aspects of the political dynamics in Huancapampa recall previous ethnographic work on patronage and clientelism. One might reduce the exchange in its most basic form to the acquisition of improved kitchens, new drains and an upgrade in village status in return for the village's support in the upcoming elections. ${ }^{74}$ Recent studies on clientelism in Latin America point to the ways in which it moves beyond merely purchasing votes and may actually serve as a modality for citizens' participation and accountability. ${ }^{75}$ This is different from previous descriptions of patron-client relations in the Andes, where dominant landowners and suppressed rural peasants were bound in perpetual relations of unbalanced reciprocity and violence. While there are certainly traits of patron-client-ship in the current configurations of the relationship between the provincial mayor and the villagers of Huancapampa, this is a much more dynamic and changing relationship. The sharing of beers and the promises that Recuay mayor Milton León made that day in Huancapampa cannot be reduced to a simple exchange of goods for votes. By dramatically striving to establish a social relationship between themselves and state actors, the leaders of Huancapampa and other political figures are insisting on being 'remembered' by the state.

So far, frameworks of client-ship have given only part of the picture of what is going on in Huancapampa. There is most certainly a degree of unbalanced reciprocity occurring between local governments and the villagers: on one level, the votes were exchanged for improved stoves and jobs. However, these exchanges proved to have impacted not only on domestic spheres. A central point here lies in the priority list that the villagers elaborated in collaboration with the NGO prior to the participatory budget meetings in Recuay. Why is it that a municipality building is so important in this little place which is only a

74 See Cameron, Struggles for Local Democracy, p. 273.

75 See, for example, Javier Auyero, 'The Logic of Clientelism in Argentina: An Ethnographic Account', Latin American Research Review, 35: 3 (2000), pp. 55-8 I; Javier Auyero, Pablo Lapegna and Fernanda Page Poma, 'Patronage Politics and Contentious Collective Action: A Recursive Relationship', Latin American Politics and Society, 51: 3 (2009), pp. I-3 I; Sian Lazar, Personalist Politics, Clientelism and Citizenship. 
I 5-minute walk from central plaza in Recuay? Why are seemingly more urgent needs not prioritised such as health (improving sanitation and water supply) or education (improving the decaying local school)? With these questions in mind, I move on to the celebration of the village upgrade held less than a month after the meeting described above.

\section{Becoming Huancapampa: State Recognition and Local Fissures}

On 2 I June 2010 , the entire population of Huancapampa gathered in the village's concrete central plaza. ${ }^{76}$ Adobe houses with cracking white paint, tin roofs and political slogans border three sides of the plaza. The Peruvian flag was hoisted on the tall, slender, slightly bent wooden pole in the centre of the square, and a green gazebo provided shade for the mayor and a number of village notables (mostly men). The different instituciones de base (mostly women and children) paraded into the small plaza, many individuals representing more than one institution. They were there to celebrate Huancapampa's accession to the status of a centro poblado menor, which would transfer small portions of authority and finance from the provincial municipality in Recuay to the local level; but, more importantly, it, together with the popular gathering, constituted a symbolic recognition of Huancapampa as, if small, nonetheless significant, and no longer rural but urban.

After the procession, the local teacher took charge of the microphone, handing it to the mayor, who gave his inaugural speech highlighting the close ties between the municipality and the villagers, and the continued development of both, reiterating his promise of drainage and concrete stoves in the upper barrio to the applause of the gathered crowd. The mayor's speech was followed by official expressions of gratitude from prominent Huancapampa people. One by one, they addressed the importance of this vital step in the continued progress of this once-abandoned or once-forgotten village. 'Today', said Nelson, the acting mayor of Huancapampa, 'the mayor has shown that he remembers who we are. We are honoured by his presence'.

Among the celebrants were Eladio and his father, Oscar, from the hamlet of Shecllapata on the plateau to the north across the River Atoq Huacanca. Óscar and Eladio represented Shecllapata's only two remaining permanent households. Administratively speaking, the hamlet of Shecllapata belongs to Huancapampa, but Huancapampa is not easy to reach from there. Using a bridge that crosses the River Santa instead of jumping from stone to stone across Atoq Huacanca to Huancapampa, Shecllapata's inhabitants have often gone straight to Recuay. As the Huancapampa schoolteacher addressed the gathering, Óscar, from one of the concrete benches that surround the ${ }^{76}$ Fieldnotes, 21, 24 and 25 June 2010. 


\section{Mattias Borg Rasmussen}

central part of the square, raised his hand and rose to his feet. The teacher nodded in recognition. With one arm gesticulating and the other kept close to his abdomen, Óscar reminded the authorities present in the square that they should not forget the hamlets. 'Huancapampa', he said, 'is not only Huancapampa'.

Óscar pleaded with the new authorities in Huancapampa not to forget the outer hamlets. The nomination of Huancapampa as centro poblado menor would change the local dynamics between the villages, and Shecllapata would now have to rely to some extent on the goodwill of the mayor of Huancapampa rather than that of Recuay. In Shecllapata, people were not entirely thrilled at the prospect of having to deal with yet another layer of bureaucracy. They feared being even more marginalised by having the capacity to decide potentially removed from Recuay to Huancapampa, giving them yet another layer of inefficient bureaucracy to deal with. Eladio, a member of the regional agrarian federation and the most eloquent of the two (and, like his father, he is known as a troublemaker), would later tell me about this sense of abandonment not only from the authorities (which we talked only a little about on this occasion) and from the fellow comuneros as the villagers in Shecllapata moved out of there, one by one, pushed out by cattle-rustlers, house-robberies and the insecurity produced by the momentary presence of Sendero Luminoso. ${ }^{77}$ To Eladio, the rusty padlocks of abandoned houses are the visible signs of failed agrarian policies that also Doña Julia lamented.

Óscar's allusion to forgetting in his brief intervention on the plaza directly invokes the idiom of abandonment. To remind the new authorities that Huancapampa 'is not only Huancapampa' is to underscore their responsibility as governors of everybody, even in this rather small territory, which stretches less than ro kilometres from the banks of the River Santa to the shores of Lake Churiac and encompasses two villages and portions of the peasant community to which many Huancapampinos belong. From the shores of Lake Titicaca, Orlove reminds us that, in the Andes, to forget is conceived as a conscious act. ${ }^{78}$ In the 'forgotten' villages Orlove studied, villagers often offered extravagant, expensive gifts of food to visiting government officials. Desperate to establish social relationships with these emissaries, they did not want to be 'forgotten'. With Huancapampa's upgrade from rural village to urban centro poblado menor, Huancapampa's officials also became capable of forgetting, and thus of leaving its vulnerable constituents in a state of 'abandonment'.

Representing the marginal hamlet of Shecllapata, Óscar expressed ambivalence about the change and stated his fears clearly. Still more hostile to Huancapampa's attempt to increase its sovereignty were the people of Ocopampa, the hamlet farther up the River Atoq Huacanca. Although now

77 Interview, 2 I March 2010.
78 Orlove, Lines in the Water. 
officially under the jurisdiction of Huancapampa, as they had previously been, the villagers of Ocopampa had unanimously decided not to attend the celebrations. Preferring to take their affairs directly to the municipality in Recuay, they were resisting the nomination of Huancapampa as a centro poblado menor. A few months later I discussed this decision with the agente municipal in Ocopampa, Don Seferino. Watching over his small flock of sheep, he expressed a profound distrust in the collective benefits of this endeavour. 'They are just minding their own businesses', he commented. 'We will become more marginalised because it will be easier for Milton [the mayor of Recuay] to forget about us.' 79 The few remaining people in Ocopampa are proud of its independence from Huancapampa through its conversion from annex (anexo) to hamlet (caserio) in I 952. For Ocopampa's villagers, the accession of Huancapampa to centro poblado menor status signalled the potential renewal of Ocopampa's subordination to the municipality. Like the people of Shecllapata, residents of Ocopampa did not want to be forgotten; but they paradoxically showed this desire by not coming, in some ways prefiguring the 'abandonment' they feared but also refusing to sign the social contact of mutual recognition.

So what is implied by this situation of new political actors capable of forgetting? What do we learn about state-citizen relations by the way in which abandonment is articulated?

\section{Figures of Abandonment: Affective Performativity in Local Politics}

To answer this, we return to the use of abandonment by turning to a meeting on the plaza in Huancapampa, the same place where the village would later receive its official recognition. Chronologically, this open-air meeting fell in between the two encounters described above: after the NGO meeting followed by beer sharing and before the official ceremony. ${ }^{8 \circ}$ The agenda of the meeting was limited: the system of potable water in the upper part of the village was not working properly, and many villagers had been left without running water from the taps outside their houses. The Recuay mayor's frequent promise of even the most modest form of drainage was yet to be fulfilled. The discussion was well under way when Nelson, the acting mayor, got to his feet, taking off his baseball cap in the same movement. 'It's always the same', he said with dignified anger, drawing a vertical line in the air with the thumb and index finger of his right hand. 'iAquí nos tienen practicamente abandonados!' [Here they are practically keeping us in abandonment!] People around him mumbled and nodded in recognition. Surely, they seemed to agree; they

79 Fieldnotes, ro August 2010.

80 Fieldnotes, 20 June 2010. 


\section{Mattias Borg Rasmussen}

could rightfully expect more from local government, not to mention the national government.

Describing not only things as they are, Nelson's comment highlighted the perceived state agency: just as forgetting is an act with intention, so the villagers in Huancapampa were not only left in abandonment. They were deliberately being kept in such a state of abandonment outside progress. It can therefore be understood as a critique of the modalities of governance by very different state institutions. The sense of abandonment is a sense of being ignored and a sense of social, economic and political exclusion. To talk of abandonment is to talk of failure and betrayal, and it points towards certain kinds of ethics, subjectivities and citizenship formations. To be abandoned is to be left by somebody who ought to have stayed; to be held in abandonment is to be put in this situation deliberately. To be governed is a delicate balancing act according to Doña Elena:

Huancapampa has improved a lot. Not we have houses, we know how to clean the streets. It is more quiet now, with the help of the señores from Visión Mundial, from ADRA. We thank them. Do you know why? They have given us toilets, water, drainage. Therefore we thank them. Because before, we did not have anything. Electricity, water. Nobody would help us. We have worked to get this ... We have worked hard like women, fighting for electricity, for water, for the school, the bridge, without earning anything. ... [To help save my house from the river], I would have to ask the mayor to divert the river with boulders ... but when you go there on your own, they never pay any attention. They say, 'you have your own mayor'.

MBR: But did you ever go to the municipal council?

This time I didn't. But last year. Milton has helped. Everytime I cried, when I called, he would come ... He has helped us. He is a good person. That is why we voted for him [in the municipal elections a month earlier]. We voted for him and he helps us. ${ }^{8}$ i

There is a notable change in this narrative: from NGOs taking over in the absence of government to the faceless, uncaring bureaucrats to the benevolence and reciprocity between the personalised mayor and the community as a collective. These are coexisting realities that can all be conjured. Three scenes have been touched upon in the process that led to the recognition of Huancapampa: the NGO-led meeting about the participatory budget, which ended in drinks with the mayor at Don Isidoro's; the ceremony celebrating the village's move upward in the state administrative hierarchy (to become a centro poblado menor); and now Nelson's frustrated outburst on the plaza of Huancapampa. From the intimacy of the encounter with the person of the mayor in the drinking-den, to

${ }^{81}$ Interview, 23 November 2010 ; for details on Doña Elena's struggles against the unruly river, see Mattias Borg Rasmussen, 'Unsettling Times: Living with the Changing Horizons of the Peruvian Andes', in Latin American Perspectives, 43: 3 (2016), pp. 73-86. 
Nelson's outright invocation of the state as absent from local affairs, to the official public gathering where Óscar confronted the authorities with his fear of a new pattern of abandonment, each of these is part of the local politics of developing Huancapampa. In different ways, each deploys the idiom of abandonment and its attendant calculation of the probabilities of forgetting.

The mayor of Recuay's two visits to Huancapampa did not change villagers' general figuration of 'abandonment'. The recognition was seen as a victory in the ongoing process of being remembered and therefore taken into consideration, even though it accentuated some of the internal tension among the different communities: Óscar's preoccupation on the small square of Huancapampa was a concern that new patterns of abandonment would emerge. The metaphors of abandonment and forgetting expressed here in the words of Nelson and Óscar and the act of conspicuous beer sharing by Pompeyo point to a social relationship that must be maintained: if there were no expectations of sociality, intimacy and connectivity, it would not make sense to talk of abandonment.

The idiom of abandonment feeds into clientelism as a political strategy by underscoring how the relationship between the 'father of the people' and the people must be constantly cared for. To link to networks of resources is to connect productively with authorities. The workings of the state are intimately linked to ideals of progress and development as well the role of public authorities in the provision of public services. ${ }^{82}$ Politics in the Andes are often framed as a matter of infrastructural development - literally, as 'sowing' cement. ${ }^{83}$ State-driven development creates promises of both material and social progress. But such promises of inclusion and development are precarious. ${ }^{84} \mathrm{~A}$ hope-generating machine, the workings of the state may often be turned into despair, as the sense of abandonment takes over from the expectations of modernity. ${ }^{85}$ It is exactly the convergence of a state-sponsored temporality of progress with the individual temporalities of limited horizons that nurtures the sense of abandonment and gives it its political leverage.

The claim that the villages surrounding Recuay are forcibly kept in a state of perpetual abandonment also serves as a critique of governance. There is a tension here: I have argued that abandonment continues to be an effective political idiom for holding local politicians and authorities accountable even when the state of affairs is arguably improving, and even though there is no reason to believe that the relationship in the past was any better. Thus, abandonment

${ }^{82}$ See also Mattias Borg Rasmussen, 'Water Futures: Contested Resources in Peru's Huascarán National Park', Anthropologica, 75 (2016, in press).

${ }^{8} 3$ See Cameron, Development is a Bag of Cement.

${ }^{84}$ Nuijten, Perversity of the Citizenship Game.

${ }^{85}$ Monique Nuijten, 'Between Fear and Fantasy: Governmentality and the Working of Power in Mexico', Critique of Anthropology, 24: 2 (2004), pp. 209-30. 


\section{Mattias Borg Rasmussen}

does not necessarily describe the level of state involvement in either absolute or relative terms. Because abandonment, as forgetting, is no coincidence, because it is perceived to be an active choice, it serves as a pertinent reminder to authorities that they will be held accountable: as such, as a shared repertoire it works both horizontally to communicate community coherence ("we are held in abandonment') and vertically to authorities at all levels ('you have chosen to keep us in abandonment'). Because it connects past experience and future expectations in the present political moment, figuring abandonment is both effective and affective.

\section{Conclusion: The Desire to be Governed}

Abandonment characterises the citizen-state relationship in a particular way. Local politics in Andean Peru is suspended between being governed and striving for local autonomy. This article has traced the political strategies that aim to position the village favourably in relation to resources. I have focused in particular on the process that led to the recognition of Huancapampa as a centro poblado menor, and the reaction from the neighbouring villages who found themselves under its jurisdiction, expressing concerns for the emergence and persistence of patterns of abandonment. The encounters described here had a number of concrete outcomes: a municipality building in Huancapampa, a drainage project in Aconan as well as the re-election of Mayor Milton in October and the subsequent hiring of a number of Huancapampinos, including acting mayor Nelson, for unskilled tasks at the municipality.

The vernaculars of citizenship show how the sense of belonging and connectivity is deeply embedded in political networks. Like studies on the so-called transitions from patronage to clientelism and beyond, the material discussed here highlights the personalistic character of citizenship in the Andes. The villagers strategically position themselves through social connections, but there is a tension between promise and deceit in state-sponsored trajectories of alleged progress. It is indeed a paradox that the idiom of abandono retains its purchase despite the investments of the state. The ideals and the pathways towards local development cannot be separated from the engagements with the state in its different guises, and the idiom of abandonment reveals that the construction of the state and citizen in the Peruvian highlands is deeply connected to imaginaries about locations, people and progress.

The desire to be governed concerns the ways in which the villagers seek to anticipate and mould the often frustrated encounters with state authorities. Abandonment has become a performative idiom in Huancapampa. Pronouncing it enables local political leaders to federate and mobilise people around a common position to contest and claim rights. Abandonment highlights the affective dimensions to citizenship by revealing people's hopes. It suggests 
their expectations of what the state should be by framing ideal-types of state authorities and citizens.

To claim one is being forcibly kept in a state of perpetual abandonment expresses a sense of disenfranchisement, and yet it must also be understood as an assertion of self-reliance. To talk of abandonment effectively positions oneself as a rightful recipient of resources even if one is not the 'most abandoned' in the descriptive sense of the word. It has deep roots in Peruvians' historical experience of governance in rural settlements. Abandonment is therefore also part of the discursive opposition to historical centralism and the concentration of power and resources with the central government in Lima and its lower-tier officials. When villages calculate their level of abandonment and discursively mobilise it in the hope of being 'remembered' and having their needs met, they are not necessarily acting in hostility to the state. They are, instead, claiming citizenship and trying to determine, access and define the terms of engagement in a given situation.

\section{Spanish and Portuguese abstracts}

Spanish abstract. El abandono se ha vuelto un idioma performativo en el Perú andino, donde mantiene su validez a pesar de las inversiones estatales. Aquí, el desarrollo local está atado al deseo de ser gobernado. A pesar de la prolongada presencia estatal, la relación de los aldeanos hacia las autoridades se configura continua y persistentemente como una de abandono: las aldeas son abandonadas porque alguien está deliberadamente manteniéndolas en condiciones desafortunadas. Señalar abandono en la política de la aldea es introducir un medio efectivo para comunicar la experiencia histórica de la gobernanza y para avanzar reclamos morales a las autoridades locales. El idioma del abandono es por lo tanto efectivo y afectivo como crítica de la gobernanza y al reclamo de ciudadanía.

Spanish keywords: Andes, Perú, política, ciudadanía, desarrollo rural

Portuguese abstract. O abandono tem tornado-se um discurso perfomativo na região andina do Peru, onde mantem seu apelo apesar de investimentos estatais. O desenvolvimento local é associado ao desejo de ser governado. Apesar da prologanda presença estatal, a relação dos aldóes com as autoridades é representada continuamente e persistentemente como de abandono: os vilarejos são abandonados porque alguém deliberadamente os mantem em condições desfavorecidas. Salientar o abandono na política dos vilarejos é utilizar este discurso como um meio efetivo tanto de comunicar a experiência histórica de governança quanto de apresentar reivindicações embasadas em questões morais às autoridades locais. Deste modo, o idioma do abandono é tanto efetivo quanto afetivo como meio de crítica à governança e como forma de reivindicar a cidadania.

Portuguese keywords: Andes, Peru, política, cidadania, desenvolvimento rural 